\title{
Between perfect habitat and ecological trap: even wildflower strips mulched annually increase pollinating insect numbers in intensively used agricultural landscapes
}

\author{
Heiko Schmied ${ }^{1,2}$ (I) $\cdot$ Larissa Getrost $^{1} \cdot$ Olaf Diestelhorst $^{3} \cdot$ Genevieve Maaßen $^{1} \cdot$ Lisa Gerhard $^{1}$
}

Received: 20 May 2021 / Accepted: 3 February 2022 / Published online: 27 February 2022

(c) The Author(s) 2022, corrected publication 2022

\begin{abstract}
The loss of biodiversity and biomass of insects has a detrimental effect on eco-systems and associated ecosystem services, e.g. pollination. For this reason, various nature conservation measures for the promotion of insects are being created in agricultural landscapes. One of those measures is the so-called flower strip at the edge of fields. However, it is repeatedly propagated in the nature conservation community that by means of annually mulched flower strips, species richness and abundance of pollinators in intensively used agricultural areas cannot be increased. Furthermore, these measures might represent ecological traps. To check this criticism, we surveyed one to three meter wide perennial wild flower strips in intensively used agricultural areas, which have been mulched annually for three years, upon abundance, species numbers and biomass of bees and butterflies. By means of transect surveys, species richness and abundance were recorded and biomass was calculated. We compared the findings with those of reference field margins. Our results show an increase in species richness and abundance as well as a general increase in biomass of wild bees and butterflies in wild flower strips compared to findings in the reference field margins.

Implications for insect conservation Our study shows that small, annually mulched wild flower strips are able to promote biodiversity of wild bees and butterflies in the intensively used agricultural landscape. Further, our results obtained that this measure does not inevitably represent an ecological trap or sink habitat for most species.
\end{abstract}

Keywords Butterflies $\cdot$ Nature conservation $\cdot$ Regional seeds $\cdot$ Wild bees $\cdot$ Wildflower

\section{Introduction}

During the last decades, several studies revealed a notable decline of insect species richness and biodiversity (Kosior et al. 2007; Goulson et al. 2008; Scheper et al. 2014). In Germany a decrease of about $75 \%$ of biomass of flying insects was recorded during 1989-2016 in nature conservation areas (Hallmann et al. 2017). Similar trends are given in

Heiko Schmied

h.schmied@rheinische-kulturlandschaft.de;

schmied@uni-bonn.de

1 Foundation of the Rhenish Cultural Landscape, Rochusstraße 18, 53123 Bonn, Germany

2 Institute of Crop Science and Resource Conservation, Agroecology and Organic Farming Group, University Bonn, Auf dem Hügel 6, 53121 Bonn, Germany

3 Büro Diestelhorst, Senefelderweg 32, 40591 Düsseldorf, Germany other European countries (Conrad et al. 2006; Valtonen et al. 2017; van Swaay et al. 2006) and worldwide (Sánchez-Bayo and Wyckhuys 2019). This development endangers important eco-system services like pollination (Biesmeijer et al. 2006), natural pest control and recycling of organic matter (Noriega et al. 2018).

Main reasons for the decrease are the loss of habitat structures, climate change and the intensification of agriculture (Steffan-Dewenter 2003; Le Féon et al. 2010; Ewald et al. 2015; Seibold et al. 2019), which causes, amongst others, losses in food plant abundance for flower-visiting insects (Abrahamczyk et al. 2020).

In Germany about $50 \%$ of the land surface is used for agriculture (including grassland) (Umweltbundesamt 2019). This extensive proportion shows that it is necessary to collaborate with local farmers, for establishing large-scale effective nature conservation measures and by that means support insect habitats (Gonthier et al. 2014). Flower strips are common nature conservation instruments 
which several countries have already introduced, e.g. as agri-environmental measures (Haaland et al. 2011) in the Common Agricultural Policy (CAP) of the European Union. However, some aspects might limit the positive effects of flower strips or even turn them into a so called 'ecological trap' (Ganser et al. 2019). For example, species might prefer them even if they show a low quality for reproduction compared to more suitable habitats. This general behaviour can lead to a decline or extinction of populations according to Battin (2004) and Gilroy and Sutherland (2007). Further negative impacts might occur due to conventional managed neighbouring fields with dispersive pesticide application (Ganser et al. 2019) or destruction of wintering habitats by mulching (Wix et al. 2018; Haaland et al. 2011; Ganser et al. 2019).

Füglistaller et al. (2018) have already concluded, for various insect groups, that annual flower strips do not act as an ecological trap. However, the authors mainly dealt with soil-associated arthropods with no wild bees being included into their analyses. Since annual flower strips cannot provide long-term habitats, some negative effects, which an ecological trap could create, cannot occur. Those effects might rather be found in nature conservation measurements, which persist for a longer period of time, like perennial flower strips which offer nesting sites. Thus the general effects on insect populations might be highly different compared to that of annual ones.

To check if perennial flower strips do actually represent such an ecological trap or other sink habitats for relevant pollinators like wild bees and butterflies, we established (CAP compliant) narrow wildflower strips in intensively used agricultural areas, which were mulched once a year. In the survey, species richness and abundance of both taxa were recorded in one, two and three year old flower strips and field margins without sown flower strips (reference margins) and biomass of the species groups was calculated retrospectively. By collecting data of the different aged flower strips over five years, annual effects could be minimized. Incoming food guest insects in the flower strips from the surrounding areas can increase the number of individuals and the biomass, but it can be assumed that the error will be balanced out over all years of investigation, or can be clearly recognized by the flower strips of different ages, especially due to the mass flowering of specific plant species. However, a strong change in species richness by food guests cannot be assumed, since the surrounding agricultural areas usually do not contain a large inventory of species which is also recorded by the examination of reference margins. According to our approach, an ecological trap or another sink habitat was assumed if species richness or the number of individuals in flower strips decrease significantly over time, while the reference areas hold constant values. However, the experimental setup did not allow the distinction between a sink habitat and a real ecological trap, but fundamental habitat suitability for the species groups can be inferred.

\section{Material and methods}

\section{Study design}

From 2014 to $2018,50 \mathrm{~km}$ of wildflower strips (in total 117 flower strips) with a width of $1 \mathrm{~m}$ (2014-2015) and $3 \mathrm{~m}$ (2016-2018), and an average length of about $430 \mathrm{~m}$ (from 96 to $5.579 \mathrm{~m}$ ) were created at the edges of intensively cultivated fields in the Lower Rhine Bay (NRW, Germany) (see Fig. 1) in cooperation with 40 non-organic farmers. The change in the width of the flower strips was due to a change in financial support for farmers at the start of the new CAP funding period. In order to compensate the difference of width, the strips already examined were widened to $3 \mathrm{~m}$, if possible.

Flower strips which are close to other flower strips or similar nature conservation measures, as well as strips which are close to roads or railroad tracks, with obvious soil compaction or shading were excluded for data acquisition. On the adjacent fields, mostly non-organic agriculture with different and changing crops (mainly winter wheat, sugar beet, corn) was operated. The use of pesticides was not recorded for the total of more than 280 neighboring areas, but regular use can be assumed regarding to cropping plans and legal situation. When selecting the respective field egdes as reference margins, attention was paid to them having the same length and neighbouring areas which are managed in a similar way.

The wildflower species list is referring to the seed mixture Feldraine auf Löss (engl.: Field border on loess) (species and quantity composition in Table S1). Only wild plant seeds of regional origin according to Prasse et al. (2011) were used. Sowing took place with pneumatic and mechanical sowing machines by farmers individually from the end of August to the end of September with a seed rate of $20 \mathrm{~kg} /$ ha combined with $80 \mathrm{~kg} / \mathrm{ha}$ of groats as a filler for better manageability. Neither fertilizer nor pesticides were used in the strips. Only a small scale, selective mechanical weed control to reduce thistle (Cirsium arvense) was allowed. However this was only applied very rarely. All flower strips were mulched once a year and reference margins at least once a year. A detailed description of the development and implementation of the measure is given in Schmied and Baum (2019).

\section{Data collection}

Wild bees and day-active butterflies were recorded between 2015 and 2019 by means of transect surveys in wildflower strips of different age (1-3 years) and in reference field 

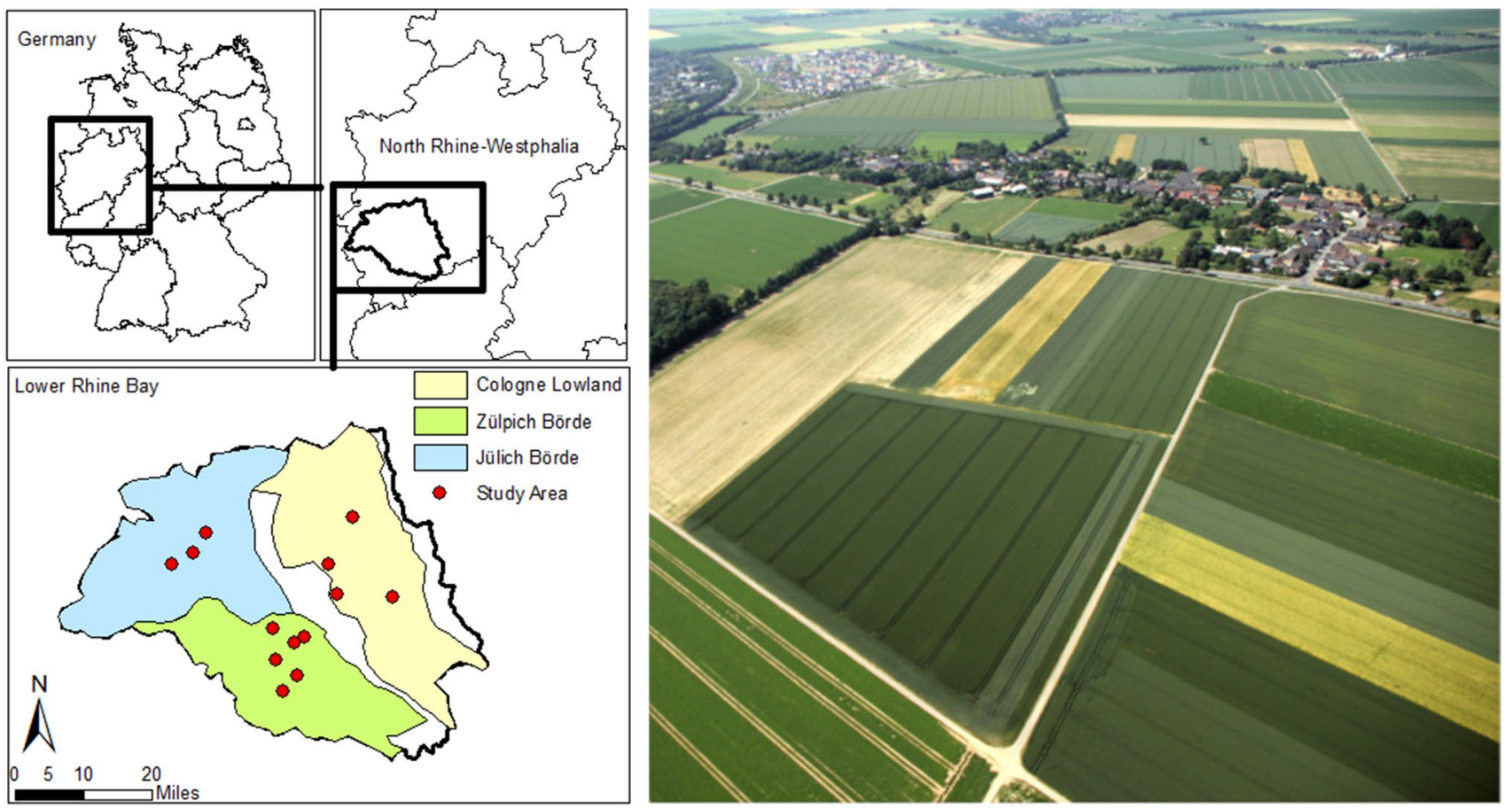

Fig. 1 Location of the study areas in the Lower Rhine Bay (North Rhine-Westphalia, Germany) (www.geoportal.nrw) with a photo of the typical landscape of the region

margins according to Schindler et al. (2013)—without using pan traps. In total 13 flower strips were part of the monitoring. In the following, the different ages of flower strips are given as age types in order to avoid confusion with the study years. To minimize local effects, we selected wildflower strips and reference field margins from three different subordinate regions (Cologne Lowland, Jülich Börde \& Zülpich Börde). Apart from 2015 with only two examination dates, five transect surveys were conducted every year between March and September. In total the transect length measured $1.300 \mathrm{~m}$ for each flower strip age type and respective reference margins. The number of transects recorded per age type varied (year $1: n=11$; years 2 and $3: n=8$; in total always $1.300 \mathrm{~m}$ ), as the length of single transects was shorter at the beginning of the study. The same number and length of transects were used in the reference margins (detailed list in Table S2). During data acquisition, no distinction was made between strips of different widths $(1 \mathrm{~m} / 3 \mathrm{~m})$ as no comprehensible differences were expected based on the results of Denys and Tscharntke (2002) and Carvell et al. (2015) plus the two widths were also distributed similarly in the respective age groups. The age types of the flower strips were examined over different years (Table S2), so that singular effects of study years were minimized. Individuals have been determined according to Settele et al. (2009) [butterflies] and Mauss (1990); Prosi et al. (2015); SchmidEgger and Scheuchl (1997); Amiet et al. (1999); Amiet et al.
(2001); Ebmer (1973); Dathe et al. (2016) [wild bees]. Great importance was attached to not taking any individuals from nature as long as they could be reliably identified in the field (by sight or by temporary capture). In the case of wild bees, the same approach was followed as in the BienABest project (Neumüller et al. 2020, 2021).

During all transect surveys, the flower cover of all plant species in the investigation areas was cumulative recorded in percentage categories $(0-1,1-5,6-19,20-49,50-100)$.

\section{Statistical analysis and calculation of biomass}

Statistical analyses were conducted in RStudio version 1.4.1106 (R Core Team 2019). To examine whether the distributions of number of species and individuals were significantly different generalized linear models (GLM) and posthoc Tukey-tests were calculated with the use of the package multcomp (Hothorn et al. 2008). Therefore, the number of species and individuals of both wild bees and butterflies were compared between the different age types of flower strips and the respective reference field margins.

In order to represent the biodiversity of the different age strips and its references, respectively, Shannon index was calculated according to Shannon (1948) in RStudio (R Core Team 2019) and the package vegan (Oksanen et al. 2020).

Pollination type (oligolectic/polylectic) and nesting behavior (soil/deadwood/plant-breeding and other cavities/ 
parasitic-multiple types possible) of all wild bee species found were determined according to Westrich (2018).

Calculation of biomass in wild bees was performed by linear regression between body length and weight described by Rogers et al. (1976). Data of the body lengths refers to Amiet et al. (1999, 2001, 2010), Amiet and Krebs (2014) and Westrich (2018). In the case of a wide range of body length due to gender or variations, the mean was used. In butterflies the calculation was carried out in two steps. Data about wingspan of all species are available from Novak and Severa (1992) and Dierl (1994), and the respective forewing length was derived according to Miller (1977). Body weight was calculated by the forewing length according to Miller (1997). Miller's equation was originally developed for hawk moths (Sphingidae), so it is assumed that the calculated biomass is higher than the actual one, due to the slimmer body shapes of the recorded butterfly species.

All data used for calculation of biomass is listed in Table S3. After weight was determined for each species of both wild-bees and butterflies, the total biomass was extrapolated for each type of flower strip and reference field margin.

\section{Results}

\section{Species richness}

For both wild bees and butterflies the average number of species increases with age (one-year old: in total 33 wild bees; 7 butterflies, to two-year old: in total 36 wild bees; 10 butterflies, and three-year old: in total 47 wild bees; 11 butterflies) (Fig. 2a, 3a). Between the one-year and threeyear old flower strips a significant increase could be found in both groups (wild bees: $\mathrm{p}<0.05$; butterflies: $\mathrm{p}<0.05$ ). In the reference field margins, species richness (in total 26, 27,28 wild bees; $6,6,5$ butterflies) was significantly lower compared to species richness in three-year old flower strips (wild bees: $p<0.01$; butterflies: $p<0.01$ ). The oneyear and two-year old flower strips showed no significant difference compared to the reference field margin.

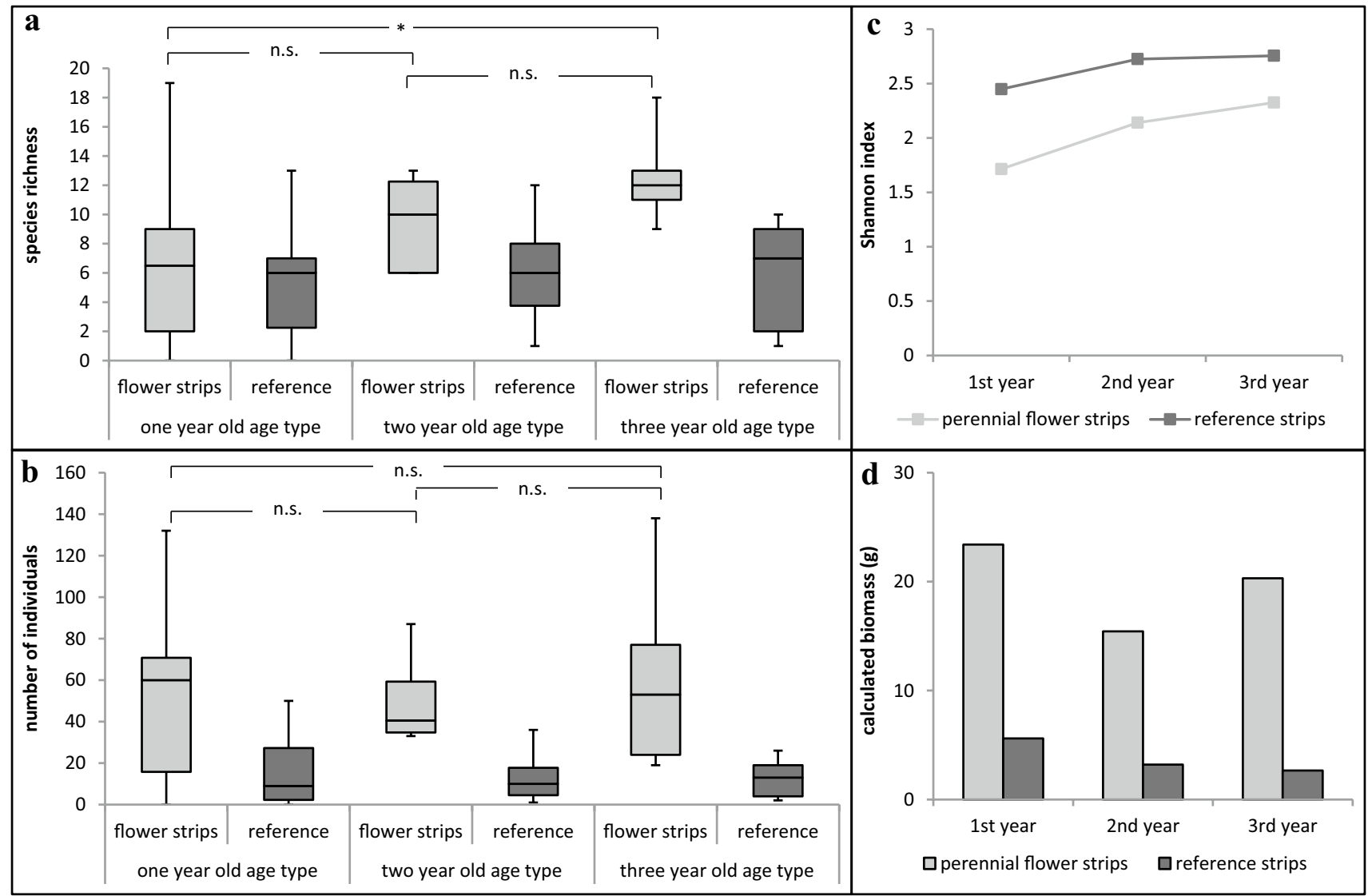

Fig. 2 Species richness (a), number of individuals (b), Shannon index (c) and calculated biomass (d) of wild bees in perennial flower strips of different age types and reference field margins in an intensively used agricultural landscape. ${ }^{*} \mathrm{p}<0.05$, n.s. $\mathrm{p}>0.05$; one year old age type: $n=11$; two year old age type and three year old age type: $n=8$ 


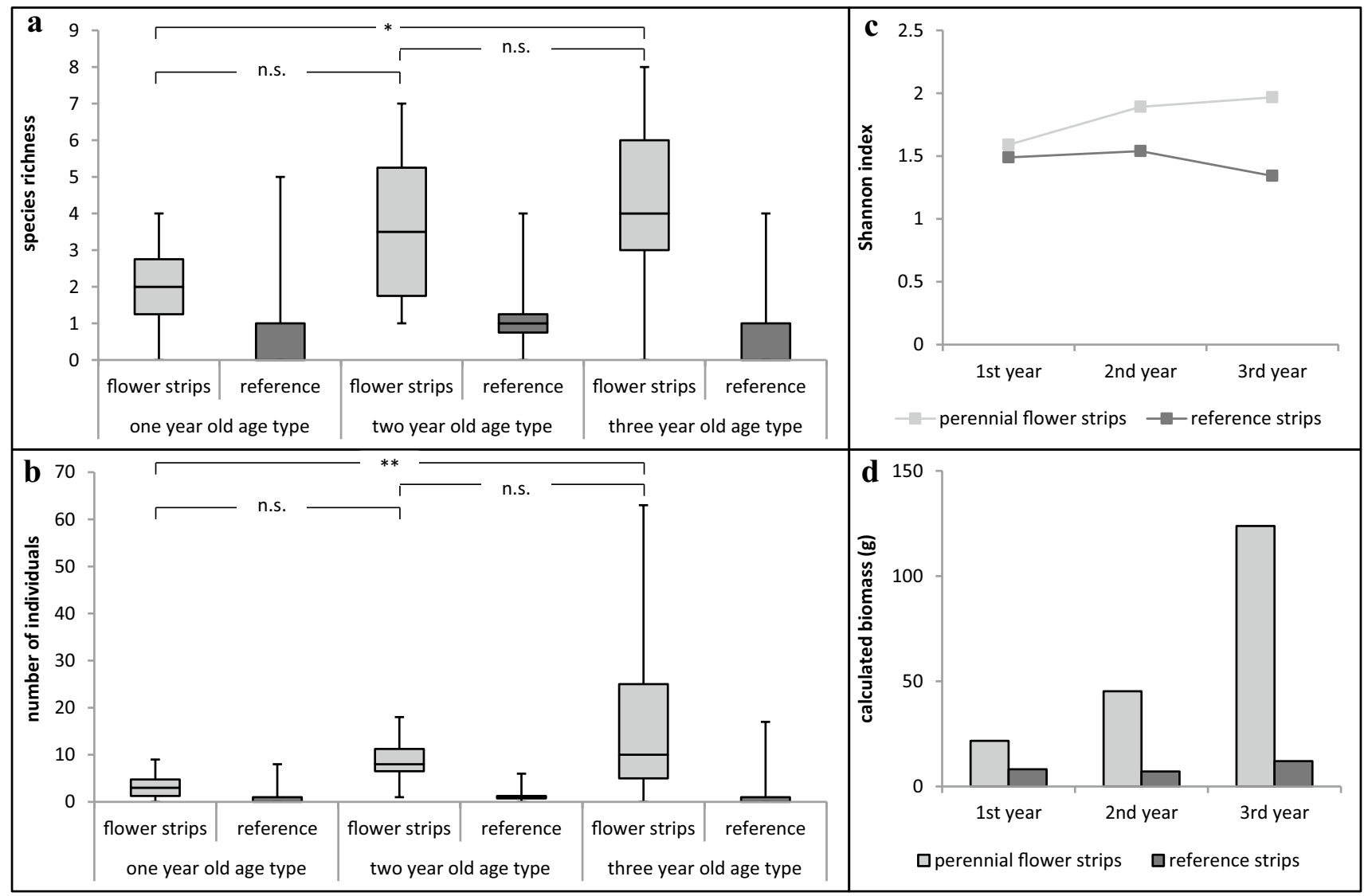

Fig. 3 Species richness (a), number of individuals (b), Shannon index (c) and calculated biomass (d) of butterflies in perennial flower strips of different age types and reference field margins in an intensively

\section{Abundance}

For both wild bees and butterflies the number of individuals showed higher values in wildflower strips than in reference field margins (Fig. 2b, 3b) (wild bees: $p<0.05$ (one-year old); $p<0.01$ (three-year old); butterflies: $p<0.01$ (threeyear old)). For wild bees the total numbers from one-year old [in total 544] to two-year old [in total 405] and three-year old strips [in total 552] showed no significant difference. In the reference field margins, the number of individuals [in total $163,110,114]$ also showed no significant differences. In the one-year and the two-year old flower strips Bombus species (mainly $B$. lapidarius and $B$. terrestris) dominated total individual numbers with $78.31 \%$ and $66.67 \%$. Without bumblebee individuals, there was an increase in the number of wild bee individuals from one-year old [in total 118], to two-year old [in total 135] and three-year old [in total 184] flower strips. In butterflies the number of individuals increased from one-year old [in total 35], to two-year old [in total 68] and three-year old [in total 158] flower strips, while the respective reference field margins showed only little variation [in total 14, 12, 22] - again with no significant used agricultural landscape. ${ }^{*} \mathrm{p}<0.05$, $* * \mathrm{p}<0.01$, n.s. $\mathrm{p}>0.05$; one year old age type: $n=11$; two year old age type and three year old age type: $\mathrm{n}=8$

differences neither in flower strips nor in reference field margins.

\section{Diversity}

For both wild bees and butterflies Shannon index increased from one-year [1.71 wild bees, 1.59 butterflies], to two-year [2.14 wild bees, 1.89 butterflies] and three-year old [2.33 wild bees, 1.96 butterflies] flower strips (Fig. 2c, 3c). For wild bee diversity in reference field margins, the index also increased continuously [2.45, 2.73, 2.76]. For butterflies the diversity in reference field margins decreased over the years $[1.49,1.54,1.34]$.

\section{Pollination type and nesting behavior}

The oligolectic species and the abundance of oligolectic individuals were similar in flower strips and reference field margins. Overall, $15 \%$ of the species and $3 \%$ of the individuals in flower strips were oligolectic species. In reference field margins the distribution of oligolectic species is similar with $17 \%$ of species and $4 \%$ of individuals (Table S4). 
Further, there could not be found significant differences in wild bee nesting types between flower strips and reference field margins.

However, the amount of wild bee species nesting above ground, e.g. inside of plants like dead flower stalks, is higher in flower strips compared to reference field margins. Here only $27 \%$ of species belong to the group of above ground nesting species, whereas in flower strips there have been found $36 \%$ of species belonging to this kind of nesting type. In comparison, the amount of ground nesting species in flower strips is lower (61\% in flower strips, $67 \%$ in reference field margins) (Table S4).

\section{Biomass}

For both wild bees and butterflies the total biomass in wildflower strips always showed higher values compared to reference field margins (Fig. 2d, 3d). In wild bees the total biomass decreased from one-year [23.4 g] to two-year old flower strips $[15.4 \mathrm{~g}]$ and increased again in three-year old [20.3 g] flower strips, while in the respective reference field margins biomass decreased from one-year, to two-year and three-year old margins [5.6 g, $3.2 \mathrm{~g}, 2.6 \mathrm{~g}$ ]. In butterflies the total biomass increased from one-year [21.7 g], to two-year $[45.3 \mathrm{~g}]$ and three-year old [123.8 g] flower strips. In the respective reference field margins biomass also increased $[8.2 \mathrm{~g}, 7.1 \mathrm{~g}, 12.0 \mathrm{~g}]$ over the years, but on a lower level. List of all species with respective weight and number of individuals for each type of flower strip and reference are listed in $\mathbf{S 4}$.

\section{Flower densities}

The highest flower densities in the year (40\% at 50-100\%) could be found in first year flower strips (Figure S1a). Twoand three-year-old flower stripes (Figure S1c, e) had lower densities (12.5\% and $22.22 \%$ at $50-100 \%)$. Reference field margins (Figure S1g) generally showed a reduced supply of flowers, with only $11.11 \%$ achieving a flower density of $20-49 \%$.

\section{Discussion}

There are several points of criticism about nature conservation measures in agricultural landscapes and especially such within the framework of the CAP (Hauck et al. 2014; Pe'er et al. 2014; Concepción et al. 2007). Flower strips have repeatedly been discussed critically in various ways (Ganser et al. 2019; Wix et al. 2019), especially because they are often disturbed by land use, characterised by a dense vegetation and they do not offer favourable nesting habitats for birds, due to high predation pressure (Bro et al.
2004; Oppermann et al. 2013; Dietzel et al. 2019). In addition, the optimal width of flower strips is often discussed which seems to be less relevant to the diversity of pollinators compared to birds. Studies could not record a significant effect of the size of flower patches on the densities of bumblebees (Carvell et al. 2015). Furthermore, Denys and Tscharntke (2002) only found a slight difference in the number of arthropods between three-meter wide strips and patches above 1 ha. To support pollinators and to preserve local plant diversity, criticism of the use of wildflower seeds from (1) non-native species or (2) non-regional seeds in flower strips is understandable. However, the use of both is banned for the open landscape in Germany since April 2020 (§ 40 Abs. 1 BNatSchG).

Further, the positioning of measures along field edges that are prone to be negatively affected by drifts of pesticides (Jauker et al. 2009; Ganser et al. 2019), as well as annual mulching (Haaland et al. 2011) is often viewed as harmful to biodiversity. With the ambition to realize conservation measures for insects on a large scale with regard to the global decline in species richness, abundance, and biomass, currently both aspects may hardly be avoidable, since most of the agricultural area is managed conventionally (in Germany 92,5\%; BMEL 2017). Furthermore, mowing of the growth, which is mostly preferred in nature conservation activities in protected areas (van de Poel and Zehm 2014), is often not feasible due to a lack of the required farm machinery, especially in regions without grassland management such as the study area. Additionally, a seasonal rotation of mulching for different parts of flower strips is often not feasible from an economical perspective (van de Poel and Zehm 2014). Due to these circumstances, it is to be expected that some pollinator species will suffer from these two limitations, e.g. concerning reproduction or hibernation.

Our results, however, reveal that species richness, abundance and biomass of wild bees and butterflies do not decrease about the three-year aging process of a flower strip. Especially in butterflies, all recorded parameters (species richness, abundance, Shannon index and biomass) increase with the age of the flower strips. Results gained for wild bees are generally similar, although biomass was highest in one-year-old flower strips. This is due to the fact that in oneyear-old flower strips a high amount of Bombus individuals was present, presumably because of a mass flowering effect of annual plant species like Centaurea cyanus and Papaver rhoeas, which caused the highest flower densities in the flower strips. Legumes also have a strong attraction to bumblebees (Pywell et al. 2005), but according to own observations from various projects the used legumes often begin to flower in the second year after sowing. In addition, the seed mixture used has a low percentage of legumes $(<5 \%)$. Overall, the proportion of oligolectic bee species is similar 
to the reference field margins, so that there was probably no one-sided promotion of polyletic species in the flower strips.

Shannon index increases with the age of the wildflower strips in both species groups, even if the values for wild bees on reference field margins were generally higher due to an overall low number of species. Similar aging effects on the diversity of arthropods are already known from Bombidae (Carvell et al. 2007; Pywell et al. 2007), Lepidoptera (Pywell et al. 2007), Carabidae and Staphylinidae (Barone and Frank 2003; Frank and Reichhart 2004). Reasons for this can certainly be the increase in plant diversity due to the later development of perennial species (e.g. Tantacetum vulgare) from the seed mixture and the partial immigration of weeds (e.g. Cirsium arvense) into the flower strips. A high number of species (annual and perennial) of site-adapted plants in flower strip mixtures is therefore the basis for an effective increase in arthropod diversity. Besides this aging effect, it cannot be excluded that enlarging of some flower strips in the study design might have also positively affected the diversity of pollinators, since combinations of old and newly established strips may attract more different species. However, both explanations for the increasing biodiversity deny the existence of an ecological trap. If the established measures would act as an ecological trap, without adequate reproduction habitats, the described increases would be assumed to occur due to an increasing growth rate of wild bee and butterfly populations in neighbouring agricultural landscapes combined with a migration to the flower strips. If this was the case, insects would migrate to flower strips and reference field margins equally and an increasing trend of species richness and abundance, as recorded for wild bees and butterflies in flower strips, should also be seen in the reference field margins. The minimum distance between flower stripes and reference field margins was an average of $958 \mathrm{~m}$, so that any possible influence on one another was minimized, but all examined areas were overall in a similar environment, so that there was no strong one-sided influence. But instead, species richness and abundance stay relatively constant in reference field margins. In addition, both values are at a significantly lower level compared to the three-year-old flower strips. This indicates that migration cannot be the only reason explaining the positive trend in flower strips.

With our study design, we cannot exclude that some individuals might die in flower strips because of the influences from neighbouring intensively used fields or mulching. This might cause the assumption of flower strips being a sink habitat for some species. However, our results make explicitly clear that flower strips cannot be seen as an ecological trap in the proper sense. Despite these possible impacts, the increase described shows, that flower strips may offer reproductive habitats for pollinators and that, as a consequence, species richness and abundance increase with growing age. For wild bees, flower strips are particularly important as a feeding habitat, as they rarely nest in flower strips with a mulch layer. But even if the mulching restricts the ground breeding species in the flower strip, the source of nutrition potentially enables the use of adjacent breeding sites (e.g. adjacent wayside), which were not populated otherwise. This possibility is supported by the knowledge that the composition of the nesting types were in general similar to that of the reference field margins, even if the number of ground breeding individuals was somewhat higher here.

Furthermore, the efficacy of different management types of field margins (e.g. natural regeneration, sowing of a wildflower mixture with annual cutting) on bumblebee abundance and richness in perennial field margins has already been studied (Carvell et al. 2007). In their study, Carvell et al. recorded an increase in both parameters in wildflower margins. Therefore, they concluded that flower strips are an effective measure to improve the quality of field edges for bumblebees, and the positve effects on insects outweigh the mulching practises (Hemmann et al. 1987). Hemmann et al. (1987) analysed the effects of mowing and mulching on bugs larvae and imagos of Tenebrio molitor. Although they did not focus on pollinators, they deduced that especially insects that rest in the vegetation during mowing/mulching, will suffer from mulching. This affects for example butterfly caterpillars and pupae, which do not have the possibility to escape (Hemmann et al. 1987). Despite these negative effects of mulching, species richness and abundance increased in the considered perennial wildflower strips.

In summary, all our results reveal that perennial wildflower strips are not only a feeding place, but also a reasonable habitat for some species of wild bees as well as butterflies and do not represent an general ecological trap, as especially species richness increases over the years. Thus, the creation of perennial flower strips with a small width, containing regional wildflowers can promote insect biodiversity and biomass in agricultural landscapes, even if adjacent fields are farmed intensively and growing plant material is mulched annually. In order to support biodiversity in the cultural landscape across the board, however, these are only one component and should, if possible, be combined with other natural protection measures.

Supplementary Information The online version contains supplementary material available at https://doi.org/10.1007/s10841-022-00383-6.

Acknowledgements The authors would like to thank Thomas Döring, Thomas Muchow, Laura Fortmann and Melanie Drews for supporting the study and their comments on the manuscript. The project Summendes Rheinland was funded in the Federal Programme for Biological Diversity by the Federal Agency for Nature Conservation with means from the Federal Ministry for the Environment, Nature Conservation and Nuclear Safety (Germany) as well by the Landwirtschaftliche Rentenbank. 
Author contributions HS, GM and LG contributed to the study conception and design. Data collection was performed by OD. Data analysis was performed by HS, LG and LG. The first draft of the manuscript was written by HS and all authors commented on previous versions of the manuscript. All authors read and approved the final manuscript. All nature conservation regulations of the state of North Rhine-Westphalia were complied with for the capture and identification of insects and the permits from the lower nature conservation authorities were available. Farmer consent was obtained for all investigations.

Funding The project Summendes Rheinland was funded in the Federal Programme for Biological Diversity by the Federal Agency for Nature Conservation with means from the Federal Ministry for the Environment, Nature Conservation and Nuclear Safety (Germany) as well by the Landwirtschaftliche Rentenbank.

Data availability The data on which the study is based are attached in an Excel file. Since the butterflies and wild bees were determined alive in the field, no collection material is available.

\section{Code availability RStudio version 1.4.1106 (R Core Team 2019).}

\section{Declarations}

Conflicts of interest The authors declare that they have no conflicts of interest.

Ethical approval Not applicable.

Informed consent All farmers involved have expressly consented to the investigations on the areas they cultivate.

Consent for publication All farmers involved in the study on their fields as well as the Federal Agency for Nature Conservation (Germany) have approved the publication.

Open Access This article is licensed under a Creative Commons Attribution 4.0 International License, which permits use, sharing, adaptation, distribution and reproduction in any medium or format, as long as you give appropriate credit to the original author(s) and the source, provide a link to the Creative Commons licence, and indicate if changes were made. The images or other third party material in this article are included in the article's Creative Commons licence, unless indicated otherwise in a credit line to the material. If material is not included in the article's Creative Commons licence and your intended use is not permitted by statutory regulation or exceeds the permitted use, you will need to obtain permission directly from the copyright holder. To view a copy of this licence, visit http://creativecommons.org/licenses/by/4.0/.

\section{References}

Abrahamczyk S, Wohlgemuth T, Nobis M, Nyffeler R, Kessler M (2020) Shifts in food plant abundance for flower-visiting insects between 1900 and 2017 in the canton of Zurich. Switz Ecol Appl. https://doi.org/10.1002/eap.2138

Amiet F, Müller M, Neumeyer R (1999) Fauna Helvetica Apidae 2: Colletes, Dufourea, Hylaeus, Nomia, Nomioides, Rhphitoides, Ropites, Sphecodes, Systropha Fauna Helvetica 4. SEG, Neuchâtel
Amiet F, Hermann M, Müller A, Neumeyer R (2001) Fauna Helvetica Apidae 3: Halictus, Lasioglossum Fauna Helvetica 6. SEG, Neuchâtel

Amiet F, Herrmann M, Müller A, Neumeyer R (2010) Fauna Helvetica Apidae 6: Andrena, Melitturga, Panurginus, Panurgus Fauna Helfetica 26. SEG, Neuchâtel

Amiet F, Krebs A (2014) Bienen Mitteleuropas. Gattungen, Lebensweise, Beobachtungen (2nd ed.). Haupt Verlag, Bern.

Barone M, Frank T (2003) Habitat age increases reproduction and nutritional condition in a generalist arthropod predator. Oecologia 135:78-83. https://doi.org/10.1007/s00442-002-1175-2

Battin J (2004) When good animals love bad habitats: Ecological traps and conservation of animal populations. Conserv Biol 18(6):1482-1491. https://doi.org/10.1111/j.1523-1739.2004. 00417.x

Biesmeijer JC, Roberts SPM, Reemer M et al (2006) Parallel declines in pollinators and insect-pollinated plants in Britain and the Netherlands. Science 313:351-354

Bro E, Mayot P, Corda E, Reitz F (2004) Impact of habitat management on grey partridge populations: assessing wildlife cover using a multisite BACI experiment. J Appl Ecol 41:846-857. https://doi.org/10.1111/j.0021-8901.2004.00939.x

Bundesministerium für Ernährung und Landwirtschaft BMEL, (ed) (2017) Daten und Fakten. Land- Forst- und Ernährungswirtschaft mit Fischerei und Wein- und Gartenbau, Berlin

Carvell C, Meek WR, Pywell RF, Goulson D, Nowakowski M (2007) Comparing the efficacy of agri-environment schemes to enhance bumble bee abundance and diversity on arable field margins. J Appl Ecol 44:29-40. https://doi.org/10.1111/j.1365-2664.2006. 01249.x

Carvell C, Bourke AFG, Osborne JL, Heard MS (2015) Effects of an agri-environment scheme on bumblebee reproduction at local and landscape scales. Basic Appl Ecol 16(6):519-530. https:// doi.org/10.1016/j.baae.2015.05.006

Concepción ED, Díaz M, Baquero RA (2007) Effects of landscape complexity on the ecological effectiveness of agri-environment schemes. Landscape Ecol 23:135-148. https://doi.org/10.1007/ s10980-007-9150-2

Conrad KF, Warren MS, Fox R, Parsons MS, Woiwod IP (2006) Rapid declines of common, widespread British moths provide evidence of an insect biodiversity crisis. Biol Cons 132:279291. https://doi.org/10.1016/j.biocon.2006.04.020

Dathe HH, Scheuchl E, Ockermüller E (2016) Illustrierte Bestimmungstabelle für die Arten der Gattung Hylaeus F. (Maskenbienen) in Deutschland. Österreich und der Schweiz. Entomologica Austriaca 1:51

Denys C, Tscharntke T (2002) Plant-insect communities and predator-prey ratios in field margin strips, adjacent fields, and fallows. Oecologia 130:315-324. https://doi.org/10.1007/s0044 20100796

Dierl W (1994) Schmetterlinge. Heimische Tagfalter und Nachtfalter (4th ed.). BLV, München

Dietzel S, Sauter F, Moosner M, Fischer C, Kollmann J (2019) Blühstreifen und Blühflächen in der landwirtschaftlichen Praxis - eine naturschutzfachliche Evaluation. Anliegen Natur 41(1):1-14

Ebmer AW (1973) Die Bienen des Genus Halictus latr. S. L. im Großraum von Linz (Hymenoptera, Apidae).Naturkdl. Jb. Linz 123:158

Ewald JA, Wheatley CJ, Aebischer NJ, Moreby SJ, Duffield SJ, Crick HQP, Morecroft MB (2015) Influences of extreme weather, climate and pesticide use on invertebrates in cereal fields over 42 years. Glob Change Biol 21:3931-3950. https://doi.org/10.1111/ gcb. 13026

Frank T, Reichhart B (2004) Staphylinidae and carabidae overwintering in wheat and sown wildflower areas of different age. Bull Entomol Res 94:209-217. https://doi.org/10.1079/BER2004301 
Füglistaller D, Lädrach C, Ramseier C et al (2018) Ökologische Fallenwirkung von einjährigen Blühstreifen -Laufkäfer als Ökozeiger. Agrarforschung Schweiz 9(6):214-217

Ganser D, Knop E, Albrecht M (2019) Sown wildflower strips as overwintering habitat for arthropodes: effective measure or ecological trap? Agr Ecosyst Environ 275:123-131. https://doi.org/10.1016/j. agee.2019.02.010

Gilroy JJ, Sutherland WJ (2007) Beyond ecological traps: perceptual errors and underevalued resources. Trends Ecol Evol 22(7):351358. https://doi.org/10.1016/j.tree.2007.03.014

Gonthier DJ, Ennis KK, Farinas S et al (2014) Biodiversity conservation in agriculture requires a multi-scale approach. Proc R Soc B 281:1-8. https://doi.org/10.1098/rspb.2014.1358

Goulson D, Lye GC, Darvill B (2008) Decline and conservation of bumble bees. Annu Rev Entomol 53:191-208. https://doi.org/10. 1146/annurev.ento.53.103106.093454

Haaland C, Naisbit RE, Bersier LF (2011) Sown wildflower strips for insect conservation: a review. Insect Conserv Divers 4:60-80. https://doi.org/10.1111/j.1752-4598.2010.00098.x

Hallmann CA, Sorg M, Jongejans E et al (2017) More than 75 percent decline over 27 years in total flying insect biomass in protected areas. PLoS ONE 12(10):1-21. https://doi.org/10.1371/ journal.pone.0185809

Hauck J, Schleyer C, Winkler KJ (2014) Maes J (2014) shades of greening: reviewing the impact of the new EU agricultural policy on ecosystem services. Change Adaption Socioecol Syst 1:51-62. https://doi.org/10.2478/cass-2014-0006

Hemmann K, Hopp I, Paulus HF (1987) Zum Einfluß der Mahd durch Messerbalken, Mulcher und Saugmäherauf Insekten am Straßenrand. Natur und Landschaft 62(3):103-106

Hothorn T, Bretz F, Westfall P (2008) Simultaneous inference in general parametric models. Biom J 50(3):346-363

Jauker F, Diekötter T, Schwarzbach F, Wolters V (2009) Pollinator dispersal in an agricultural matrix: opposing responses of wild bees and hoverflies to landscape structure and distance from main habitat. Landscape Ecol 24:547-555. https://doi.org/10. 1007/s10980-009-9331-2

Kosior A, Celary W, Olejniczak P, Fijal J, Król W, Solarz W, Plonka P (2007) The decline of the bumble bees and cuckoo bees (Hymenoptera: Apidae: Bombini) of Western and Central Europe. Oryx 41(1):79-88. https://doi.org/10.1017/S003060530 7001597

Le Féon V, Schermann-Legionnet A, Delettre Y et al (2010) Intensification of agriculture, landscape composition and wild bee communities: a large scale study in four European countries. Agric Ecosyst Environ 137(1-2):143-150. https://doi.org/10. 1016/j.agee.2010.01.015

Mauss V (1990) Bestimmungsschlüssel für die Hummeln der Bundesrepublik Deutschland (3rd ed.). DJN, Hamburg

Miller WE (1977) Wing measure as a size index in Lepidoptera: the family Olethreutidae. Ann Entomol Soc Am 70:253-256. https://doi.org/10.1093/aesa/70.2.253

Miller WE (1997) Body weight as related to wing measure in hawkmoths (Sphingidae). J Lepidopterists Soc 51:91-92

Neumüller U, Burger H, Krausch S, Blüthgen N, Ayasse M (2020) Interactions of the local habitat type, landscape composition and flower availability moderate wild bee communities. Landscape Ecol 35:2209-2224. https://doi.org/10.1007/ s10980-020-01096-4

Neumüller U, Burger H, Schwenniger HR, Hopfenmüller S, Krausch S, Weiß K, Ayasse M (2021) Prolonged blooming seasons of flower plantings increases wild bee abundance and richness in agricultural landscapes. Biodivers Conserv 30:3003-3021. https://doi.org/10.1007/s10531-021-02233-4
Noriega JA, Hortal J, Azcárate FM et al (2018) Research trends in ecosystem services provided by insects. Basic Appl Ecol 26:8-23. https://doi.org/10.1016/j.baae.2017.09.006

Novak I, Severa F (1992) Der Kosmos-Schmetterlingsführer, 5th edn. Kosmos, Stuttgart

Oppermann R, Haider M, Kronenbitter J, Schwenninger HR, Tornier I (2013) Blühflächen in der Agrarlandschaft - Untersuchungen zu Blühmischungen, Honigbienen, Wildbienen und zur praktischenUmsetzung. Gesamtbericht zur wissenschaftlichen Begleituntersuchungen im Rahmen des Projekts Syngenta Bienenweide 1:191

Pe'er G, Dicks LV, Visconti P et al (2014) EU agricultural reform fails biodiversity. Science 344(6188):1090-1092. https://doi. org/10.1126/science. 1253425

Prasse R, Kunzmann D, Schröder R (2011) Forschungsprojekt Regiosaatgut. Grundlagen fürbundeseinheitliche Regionalisierung der Wildpflanzenproduktion (Saat- und Pflanzgut). Natur in NRW 2:30-32

Prosi R, Mauss V, Kämpf R (2015) Bestimmungstafeln für die Hummeln Baden-Württembergs. Eigenverlag, Crailsheim

Pywell RF, Warmann EA, Carvell C, Sparks TH, Dicks LV, Bennett D, Wright A, Critchley CNR, Sherwood A (2005) Providing foraging resources for bumblebees in intensively farmed landscapes. Biol Cons 121(4):479-494. https://doi.org/10.1016/j. biocon.2004.05.020

Pywell RF, Meek WR, Carvell C, Hulmes L, Nowakowski M (2007) The Buzz project: Biodiversity enhancement on arable land under the new agri-environment schemes. In Boatman $\mathrm{N}$ et al. (ed.) Delivering Arable Biodiversity. Association of Applied Biologists, Wellesbourne, pp 61-68. (Aspects of Applied Biology, 81, 81)

R Core Team (2019) R: A language and environment for statistical computing. R Foundation for statistical Computing, Vienna, Austria. URL https://www.R-project.org/. Accessed 16 Mar 2020

Rogers LE, Hinds WT, Buschbom RL (1976) A general weight vs length relationship for insects. Annals Entomol Soc Am 69(2):387-389

Sánchez-Bayo F, Wyckhuys KAG (2019) Woldwide decline of the entomofauna. A review of tits drivers. Biol Cons 232:8-27. https://doi.org/10.1016/j.biocon.2019.01.020

Scheper J, Reemer M, van Kats R et al (2014) Museum specimens reveal loss of pollen host plants as key factor driving wild bee decline in the Netherlands. Proc Natl Acad Sci USA 111(49):17552-17557. https://doi.org/10.1073/pnas.14129 73111

Schindler M, Diestelhorst O, Härtel S, Saure C, Schanowski AM, Schwenninger HR (2013) Monitoring agricultural ecosystems by using wild bees as environmental indicators. BioRisk 8:5371. https://doi.org/10.3897/biorisk.8.3600

Schmid-Egger C, Scheuchl E (1997) Illustrierte Bestimmungstabellen der Wildbienen Deutschlands und Österreichs. Band III: Andrenidae. Eigenverlag. Velden

Schmied H, Baum C (2019) Naturschutz in der Agrarlandschaft Methoden zum Erhalt und zur Förderung derbiologischen Vielfalt am Beispiel von zwei Projekten. Natur in NRW 1:24-29

Seibold S, Gossner MM, Simons NK et al (2019) Arthropod decline in grassland and forests is associated with landscapelevel drivers. Nature 574:671-674. https://doi.org/10.1038/ s41586-019-1684-3

Settele J, Steiner R, Reinhardt R, Feldmann R, Hermann G (2009) Schmetterlinge. Die Tagfalter Deutschlands (2nd ed.). Verlag E. Ulmer, Stuttgart

Shannon C (1948) A mathematical theory of communication. Bell Syst Technol J 27:379-423 
Steffan-Dewenter I (2003) Importance of habitat area and landscape context for species richness of bees and wasps in fragmented orchard meadows. Conserv Biol 17(4):1036-1044. https://doi. org/10.1046/j.1523-1739.2003.01575.x

Umweltbundesamt (ed.) (2019) Struktur der Flächennutzung. https:// www.umweltbundesamt.de/daten/flaeche-boden-land-oekos ysteme/flaeche/struktur-der-flaechennutzung\#die-wichtigstenflachennutzungen. Accessed 15 June 2020

Valtonen A, Hirka A, Szocs L, Ayres MP, Roininen H, Csoka G (2017) Long-term species loss and homogenization of moth communities in Central Europe. J Anim Ecol 86:730-738. https://doi.org/10.1111/1365-2656.12687

van de Poel D, Zehm A (2014) Die Wirkung des Mähens auf die Fauna der Wiesen - eine Literaturauswertungfür den Naturschutz. Anliegen Natur 36(2):36-51

van Swaay C, Warren M, Loïs G (2006) Biotope use and trends of European butterflies. J Insect Conserv 10:189-209. https://doi. org/10.1007/s10841-006-8361-1
Westrich P (2018) Die Wildbienen Deutschlands. Eugen Ulmer, Stuttgart

Wix N, Rode M, Reich M (2018) Auswirkungen von Blühstreifen auf die Biodiversität und ihre Eignung alsproduktionsintegrierte Kompensationsmaßnahme (PIK) bei der Biogasproduktion. Umwelt Und Raum 9:7-46

Wix N, Reich M, Schaarschmidt F (2019) Butterfly richness and abundance in flower strips and field margins: the role of local habitat quality and landscape context. Heliyon 5(5):1-12. https://doi.org/ 10.1016/j.heliyon.2019.e01636

Publisher's Note Springer Nature remains neutral with regard to jurisdictional claims in published maps and institutional affiliations. 